\title{
MENANGKAL GERAKAN RADIKALISME ISLAM \\ MELALUI SEKOLAH
}

\author{
Taslim Syahlan \\ Universitas Wahid Hasyim Semarang \\ Email: Taslim_syahlan@yahoo.com
}

\begin{abstract}
Radikalisme Agama merupakan permasalahan yang sering muncul di masyarakat. Akhir-akhir ini, gerakan ISIS menjadi perhatian serius di kalangan umat Islam di dunia, karena keberadaannya telah merugikan beberapa belah pihak dan telah menimbulkan banyak korban berjatuhan. Sebagai upaya pencegahan radikalisme agama, sekolah menjadi sarana efektif guna membendung gerakan tersebut. Tulisan ini menjelaskan tentang pemahaman radikalisme agama, faktor penyebab sekaligus penyebaran gerakan radikalisme serta upaya sekolah dalam menangkal radikalisme. Beberapa upaya dapat dilakukan oleh pihak sekolah, di antaranya yaitu; 1) menjelaskan ajaran Islam secara memadai kepada peserta didik; 2)mengedepankan dialog dalam pembelajaran agama Islam; 3)Pemantauan dan monitoring keagamaan peserta didik dan 4) pengenalan dan penerapan pendidikan multikultural.
\end{abstract}

Kata kunci: Radikalisme, Islam dan Sekolah

\begin{abstract}
Abstrak
Religious radicalism is a problem that often arises in the community. Lately, ISIS movement became a serious concern among Muslims in the world, because its existence has harmed some parties and has caused many victims. As prevention of religious radicalism, the school becomes an effective tool to stem the movement. This paper describes the understanding of religious radicalism, the factors causing the spread of radicalism at the same time and efforts in countering radicalism school. Some efforts can be undertaken by schools, among which; 1) explaining the teachings of Islam adequately to learners; 2) promote dialogue in learning Islamic religion; 3) Monitoring and monitoring of religious students and 4) the introduction and application of multiculture.
\end{abstract}

Keywords: radicalism, Islam, school 


\section{A. Pendahuluan}

Saat ini, dunia Islam tengah digemparkan dengan maraknya kelompok Islam radikal. Kelompok ini memunculkan keresahan bagi mayoritas umat Islam tatkala mereka tengah hidup berdampingan secara damai. Islam yang syarat akan nilai kemanusiaan, kedamaian, dan kebajikan, kini telah ternodai atas sikap kelompok yang mengatasnamakan Islam, namun melakukan cara atau tindakan yang bertentangan dengan prinsip serta ajaran Islam. Padahal sudah jelas, peperangan dan permusuhan merupakan sesuatu yang harus dihindari, sedangkan Islam pun tidak pernah mengajarkan umatnya untuk melakukan kekerasan. Hal ini sesuai dengan firman Allah Swt yaitu "Islam adalah agama yang cinta damai. Karena itu, Islam sejatinya tidak suka perang. Perang hanyalah pintu darurat (emergency exit) yang tidak dikehendaki atau keterpaksaan (QS AlBaqarah: 216). Berpedoman pada ayat tersebut, maka umat Islam sedapat mungkin berusaha untuk tidak melakukan tindakan kekerasan, terlebih lagi dengan mengatasnamakan Islam.

Munculnya radikalisme di beberapa wilayah Timur Tengah, telah memicu kemarahan dan kekhawatiran bagi umat Islam. ISIS (Islamic State Iraq and Syiria) dalam hal ini menjadi sorotan dunia melalui berbagai tindakan yang telah menimbulkan banyak jatuh korban. Di Baghdad, Kelompok ISIS membunuh sedikitnya 500 warga sekte Yazidi Iraq. Beberapa perempuan dan anak yang menjadi korban dengan dikubur hidup-hidup ${ }^{1}$. Pasca kejadian tersebut, tokoh cendekiawan Turki, Fethullah Gullen turut prihatin atas kekerasaan yang terus berlanjut dan bertambah parah tersebut. Fethullah Gulen menyerukan kepada orang-orang di seluruh dunia yang masih memiliki nurani untuk segera menghentikkan tindakan kejam yang tidak berperikemanusiaan itu².

Peristiwa penembakan dan bom bunuh diri yang terjadi di Paris beberapa waktu lalu juga menjadi pertanda bahwa radikalisme dalam agama telah mengakar sebegitu kuat. Tidak kurang 153 korban tewas atas

\footnotetext{
${ }^{1}$ Dikutip dari http://international.sindonews.com/read/889847/43/isis-bunuh500-warga-yazidi-korban-dikubur-hidup-hidup diunduh pada tanggal 1 Oktober 2014.

2 Dikutip dari http://www.indozaman.com/cendekiawan-turki-fethullah-gulenprihatin-atas-jatuhnya-korban-akibat-militan-isis/ diunduh pada tanggal 1 Oktober 2014.
} 
kejadian tersebut ${ }^{3}$. Pasca peristiwa itu, aktivitas warga menjadi sepi. Banyak pertokoan dan pusat keramaian sudah di bawah kendali keamanan ke level tertinggi.

Peristiwa di atas merupakan beberapa bentuk kekerasan yang dilakukan oleh kelompok ISIS, yang sekaligus menjadi dorongan kita sebagai kaum terdidik untuk meneguhkan kembali semangat Islam yang cinta damai, Islam yang gandrung akan hak-hak setiap manusia serta bersikap santun dalam menyampaikan pesan Allah Swt. Islam datang membawa pesan damai yang diperuntukkan bagi seluruh semesta alam, bukan untuk menimbulkan pertumpahan darah ataupun perselisihan. Meski demikian, kita patut memaklumi keadaan sosial yang mengarah pada perselisihan. Kesemuanya itu disebabkan oleh cara pandang yang berbeda, dan yang paling penting adalah jangan sampai kita ikut larut dan terjerumus dalam cara keberagamaan yang sempit. Apabila ini terjadi, dikhawatirkan kelompok ISIS dapat mempengaruhi pola pikir masyarakat serta berdampak luas bagi keberlangsungan hidup umat Islam di Indonesia.

Salah satu yang melatarbelakangi gerakan radikalisme Islam muncul adalah adanya pemahaman dan cara pandang yang sempit dalam memaknai teks yang tertuang di dalam al-Qur'an, misalnya konsep jihad. Jihad dalam hal ini dimaksudkan berperang. Padahal pada era seperti sekarang ini, peperangan dilakukan melalui ilmu pengetahuan, bukan semata-mata dimaknai dengan mengangkat senjata dan saling membunuh antara satu dengan yang lainnya. Ketika menganggap pandangannya paling benar, kemudian menyalahkan pandangan kelompok lain, dengan serta merta mengadakan perlawanan dan sebagainya. Oleh karena itu, kemunculan paham ini harus diwaspadai dengan serius agar tidak merambah pada umat Islam. Adanya terorisme, keinginan dibentuknya khilafah Islamiyah, tidak lain didorong oleh pemahaman teks yang tidak mampu mereka sinergiskan dengan konteks perkembangan sosial yang dinamis.

Berbagai cara dan strategi harus dilakukan oleh segenap komponen masyarakat untuk menghadapi kelompok radikal yang muncul akhir-akhir ini. Apabila masyarakat tidak diberikan pendidikan tentang wawasan keberagamaan yang baik, dikhawatirkan dapat mempengaruhi pola dan

\footnotetext{
3 Dikutip dari http://jabar.tribunnews.com/korban-tewas-penembakan-dan-bombunuh-diri-di-paris-jadi-153-orang pada tanggal 14 November 2015.
} 
prilaku masyarakat dalam merespon isu khilafah Islamiyah tersebut. Selain tokoh agama dan masyarakat tetap melakukan pendampingan dalam merespon isu tersebut, lembaga pendidikan juga harus mulai serius untuk membentengi pengetahuan siswanya agar tidak terpengaruh dalam cara pandang tersebut.

Sekolah merupakan wahana strategis dalam menyemaikan kebenaran ajaran Islam pada diri manusia, terutama bagi kalangan generasi pemuda. Sekolah menjadi tumpuan besar dalam menguatkan identitas Islam. Fenomena di atas sangat mengkhawatirkan terutama bagi masyarakat yang secara aqidah dan wawasan keberagamaannya masih kurang. Di satu sisi, seorang pemuda akan dengan mudah terjebak pada pandangan sempit apabila tidak diberikan wawasan keberagamaan yang baik. Melalui berbagai macam upaya dari pihak sekolah perlu dilaksanakan agar keberlangsungan perilaku keberagamaan siswa dapat berjalan sesuai dengan ajaran dan tuntunan Islam.

\section{B. Memaknai Radikalisme dalam Islam}

Istilah radikalisme berasal dari bahasa Latin "radix" yang artinya akar, pangkal, bagian bawah, atau bisa juga berarti menyeluruh, habishabisan dan amat keras untuk menuntut perubahan. Menurut Kamus Besar Bahasa Indonesia (KBBI) radikalisme berarti a) paham atau aliran yang radikal dalam politik; b) paham atau aliran yang menginginkan perubahan atau pembaharuan sosial dan politik dengan cara kekerasan atau drastis; c) sikap ekstrem dalam aliran politik4. Secara terminologi, Radikalisme dalam studi ilmu sosial diartikan sebagai pandangan yang ingin melakukan perubahan yang mendasar sesuai dengan interpretasinya terhadap realitas sosial atau ideologi yang dianutnya ${ }^{5}$. Sedangkan menurut Harun Nasution memberikan pemahaman radikalisme merupakan sebuah gerakan yang berpandangan kolot dan sering menggunakan kekerasan dalam mengajarkan keyakinan mereka ${ }^{6}$. Sementara itu, Islam merupakan agama kedamaian yang mengajarkan sikap berdamai dan mencari perdamaian ${ }^{7}$.

\footnotetext{
${ }^{4}$ Depdiknas,. Kamus Bahasa Indonesia (Jakarta: Depdiknas, 2008), hal. 1158-2

${ }^{5}$ Hasani et. all, Ismail, Radikalisme Islam di Jabotabek dan Jawa barat: Implikasinya terhadap Jaminan Kebebasan Beragama/ Berkeyakinan, (Jakarta: SETARA INSTITUTE, 2011), hal. 3

6 Harun Nasution, Islam Rasional (Bandung: Mizan, 1995), hal. 124

7 Nurcholis Madjid, Islam Agama Peradaban; Mencari Makna dan Relevansi Doktrin Islam dalam Sejarah (Jakarta: Paramadina, 1995), hal. 260
} 
Islam tidak pernah membenarkan praktek penggunaan kekerasan dalam menyebarkan agama, paham keagamaan serta paham politik.

Memang tidak dapat dipungkiri bahwa dalam perjalanan sejarahnya terdapat kelompok-kelompok Islam tertentu yang menggunakan jalan kekerasan untuk mencapai tujuan politis atau mempertahankan paham keagamaannya secara kaku yang dalam bahasa peradaban global sering disebut kaum radikalisme Islam. Istilah radikalisme untuk menyebut kelompok garis keras dipandang lebih tepat ketimbang fundamentalisme, karena fundamentalisme sendiri memiliki makna yang interpretables. Dalam tradisi pemikiran teologi keagamaan, fundamentalisme merupakan gerakan untuk mengembalikan seluruh perilaku dalam tatanan kehidupan umat Islam kepada Al-Qur'an dan AlHadits 9 .

Ermaya berpendapat bahwa radikalisme adalah paham atau aliran radikal dalam kehidupan politik. Radikal merupakan perubahan secara mendasar dan prinsip. Secara umum dan dalam ilmu politik, radikalisme berarti suatu konsep atau semangat yang berupaya mengadakan perubahan kehidupan politik secara menyeluruh, dan mendasar tanpa memperhitungkan adanya peraturan-peraturan konstitusional, politis, dan sosial yang sedang berlaku. Ada juga menyatakan bahwa radikalisme adalah suatu paham liberalisme yang sangat maju dan ada pula yang menginterpretasikan radikalisme sama dengan ekstremisme. Terminologi "radikalisme" memang dapat saja beragam, tetapi secara essensial adanya pertentangan yang tajam antara nilai-nilai yang diperjuangkan oleh kelompok agama tertentu di satu pihak dengan tatanan nilai yang berlaku saat itu. Adanya pertentangan yang tajam itu menyebabkan konsep radikalisme selalu dikaitkan dengan sikap dan tindakan yang radikal, yang kemudian dikonotasikan dengan kekerasan secara fisik ${ }^{10}$.

Islam sebagai agama yang damai sesungguhnya tidak membenarkan adanya praktik kekerasan. Cara-cara radikal untuk mencapai tujuan politis atau mempertahankan apa yang dianggap sakral

8 Muhammad Imarah, Fundamentalisme dalam Perspektif Barat dan Islam, Terjemahan Abdul Hayyie al-Kattani (Jakarta: Gema Insani Press, 1999), hal. 22

${ }^{9}$ Kuntowijoyo, Identitas politik Umat Islam (Bandung: Mizan, 1997), hal. 49

10 Ermaya Suradinata, Radikalisme dan Masa Depan Bangsa. Makalah Seminar Nasional "Masa Depan Bangsa dan Radikalisme Agama" diselenggarakan oleh Fakultas Ushuluddin, IAIN Sunan Gunung Jati Bandung pada tanggal 17 Juni 2004, hal. 1 
bukanlah cara-cara yang Islami. Di dalam tradisi peradaban Islam sendiri juga tidak dikenal adanya label radikalisme ${ }^{11}$. Dengan demikian, radikalisme dapat dipahami sebagai paham keagamaan yang mengacu pada fondasi agama yang sangat mendasar, fanatik keagamaanya cukup tinggi, tidak jarang penganut paham ini menggunakan kekerasan dalam mengaktualisasikan paham keagamaan yang dianut dan diyakininya. Kaum radikalis menginginkan adanya perubahan atau pembaruan sosialkeagamaan secara mendasar dengan sistem atau tata nilai baru yang diyakininya. Radikalisme tidak saja berupa paham atau ideologi keagamaan yang bersifat wacana dan pemikiran, pada batas-batas tertentu paham ini dapat menjelma dalam bentuk gerakan dan aksi-aksi di lapangan.

\section{Faktor Penyebab Munculnya Radikalisme}

Berbagai macam kelompok radikalisme muncul, bukan serta merta tidak memiliki alasan yang jelas dan kuat. Menurut kerangka pemikiran Islam radikal, hal tersebut pada dasarnya di antaranya adalah; a) Islam harus menjadi dasar negara; b) Syariat harus diterima sebagai konstitusi negara; c) Kedaulatan politik ada di tangan Tuhan; d) Gagasan tentang negara-bangsa (nation-state) bertentangan dengan konsep umat yang tidak mengenal batas-batas politik atau kedaerahan; e) Prinsip syura (musyawarah) berbeda dengan gagasan demokrasi ${ }^{12}$.

Afif Muhammad dijelaskan bahwa salah satu faktor pemicu munculnya radikalisme Islam adalah pemahaman normatif terhadap Islam yang bersifat tekstual, berorientasi ke masa lalu, eksklusif, dan menolak rasio dalam masalah agama. Pemahaman ini, menurutnya, dianut oleh kelompok yang menamakan diri salafiah atau wahabiah, yang di Indonesia ternyata cukup berkembang. Pemahaman seperti ini melahirkan sikap eksklusif dan menutup diri terhadap agama lain dan juga pemahaman pihak lain sesama Muslim. Kondisi ini menyebabkan pernyataan sesat dan kafir merebak, bukan saja hanya ke pada non-Muslim, tetapi juga ke sesama kaum muslim ${ }^{13}$.

11 Syamsul Bakhri. Islam dan Wacana Radikalisme Agama Kontemporer. Jurnal DINIKA Vol 3. No. 1 January, 2004, hal. 1

12 Khamami Zada, Islam Radikal; Pergulatan Ormas-ormas Islam Garis Keras di Indonesia. Jakarta: Teraju, 2002), hal. 11

${ }^{13}$ Afif Muhammad, Konflik Sosial; Studi Pengalaman di Indonesia (Bandung: Marja, 2013), hal. 5 
Hal ini diperparah lagi dengan sikap tokoh-tokoh agama yang adakalanya memprovokasi umat melakukan tindakan kekerasan. Hasil penelitian dalam bukunya di atas menunjukkan bahwa terdapat tokoh agama -baik Kristen maupun Islam- yang selalu menyampaikan khutbah dan ceramah yang dapat memprovokasi dan menghasut umat untuk melakukan tindak kekerasan.Mereka juga menyebarkan pamflet, brosur, buletin, dan buku-buku. Dari sinilah, agama dipicu menjadi radikal.

Nuhrison M. Nuh dalam tulisannya juga memberikan penjelasan mengenai penyebab munculnya gerakan radikal Islam, yaitu

1. Adanya krisis ijtihad. Sejak akhir abad ke $4 \mathrm{H}$, umat Islam mengalami stagnasi pemikiran, dan dalam beberapa hal justru dinilai mengalami kemunduran. Setelah munculnya ulama-ulama besar terutama dalam bidang Fikih dan Hadits seperti Imam Abu Hanifah, Imam Malik, Imam Syafi'i, Bukhori, Muslim dan pengarang Kitab Hadits Enam (Kutub AsSittah), di kalangan umat Islam tidak lagi berkembang para mujtahid yang mampu mengembangkan ijtihad yang melahirkan pemikiran orisinal melebihi para ulama besar di atas.

2. Krisis kepemimpinan umat Islam. Setelah Baghdad jatuh ke tangan pasukan Mongol, kepemimpinan umat Islam seolah tidak menentu, terutama karena adanya pertentangan politik yang terus menerus antarpara pemimpin Islam. Kondisi ini menyebabkan kepemimpinan umat islam menjadi lemah, tidak mampu memberdayakan potensi para ulama dan cendekiawan, yang pada gilirannya pemikiran baru Islam tidak dapat berkembang secara maksimal.

3. Berkembangnya kegiatan umat Islam yang cenderung berorientasi pada dunia mistis, tahayul, dan khurafat seperti memuja kuburan Nabi, ulama, tokoh tarekat, sufi, para wali yang telah meninggal dalam rangka mengharapkan berkah, mukjizat, perbaikan hidup yang tidak alami. Kegiatan ini telah mendorong umat Islam menjauhi inovasi dan kemajuan duniawi, yang dibutuhkan dalam membangun umat Islam yang kuat ${ }^{14}$.

${ }^{14}$ Nuhrison M. Nuh, Faktor-faktor Penyebab Munculnya Faham atau Gerakan Islam Radikal di Indonesia, (Jurnal Harmoni Vol.VIII, No. 30, April - Juni 2009), hal. 31 


\section{Penyebaran Faham Radikal dalam Islam}

Para pendukung faham radikal Islam menggunakan berbagai sarana dan media untuk menyebarluaskan faham mereka, baik dalam rangka pengkaderan internal anggota maupun untuk kepentingan sosialisasi kepada masyarakat luas. Berikut ini sarana yang ditempuh untuk menyebarluaskan faham radikalis, yaitu :

1. Melalui pengkaderan organisasi. Pengaderan organisasi adalah kegiatan pembinaan terhadap anggota atau calon anggota dari organisasi simpatisan atau pengusung radikalisme. Pertama Pengkaderan internal. Pengkaderan internal biasanya dilakukan dalam bentuk training atau pelatihan calon anggota baru dan pembinaan anggota lama. Rekruitmen calon anggota baru dilakukan baik secara individual maupun kelompok. Melalui proses pengkaderan inilah, doktrin dimasukkan sebagai bekal calon aggota untuk lebih mendalami maksud dan arah perjuangan kelompok radikalisme. Bahkan tempat yang digunakan untuk pelatihan jauh dari hiruk pikuk dunia luar agar lebih fokus dalam mengkaji materi sekaligus mendiskusikannya. Pada prinsipnya, mereka tidak perlu banyak orang, sedikit namun memberikan doktrinasi luar biasa pada diri setiap peserta.

2. Melalui masjid-masjid yang berhasil "dikuasai". Kelompok Islam radikal juga sangat lihai memanfaatkan masjid yang kurang "diurus" oleh masyarakat sekitar. Partisipasi aktif mereka seperti berjamaah serta membuat majlis kecil untuk berdialog, kerap pula melahirkan simpati pada masyarakat. Pada akhirnya, sebagian masyarakat berkenan untuk bergabung dalam kelompok kecil itu. Setelah merasakan nyaman dan kecocokan dalam berbagai pandangan, kemudian wacana yang mengarah pada paham radikal dimasukkan. Perhatian serta motivasi yang diberikan oleh kelompok radikal sangat besar. Tidak hanya bertemu di majlis atau tempat peribadatan, melainkan seringkali kelompok radikal berkunjung ke rumah secara bersama-sama dan melakukan diskusi yang bersifat mengajak.

3. Melalui majalah, buletin, dan booklet. Penyebaran ideologi radikalisme juga dilakukan melalui majalah dan buletin. Kita seringkali pula menjumpai berbagai macam tulisan yang beredar di sekitar masjid, sekolah atau tempat umum lainnya. Biasanya buletin yang ada, memberikan kesan Islami dan nuansa religius, sehingga banyak orang tertarik untuk membaca dan mempelajarinya. Ditambah lagi dengan 
banyaknya orang yang tidak tahu arah dan tujuan, menjadikan diri mereka mudah hanyut dalam ajakan tersebut. Kesan yang disampaikan sungguh santun dan bersifat mengajak dalam kebaikan. Surga dan pahala yang berlipat menjadi kekuatan untuk memancing orang yang membaca untuk bersama-sama berjuang di jalan Allah. Baginya itu adalah jalan yang dianggap paling baik. Tidak jarang pula si pembaca, mengikuti secara intens setiap pertemuan yang ada. Beberapa bagian tulisan sering memperlihatkan jadwal kegiatan rutin yang dilaksanakan di salah satu tempat. Tatkala orang yang belum tahu benar maksud dan tujuan tersebut, biasanya mereka akan datang dan mengikutinya.

4. Melalui penerbitan buku-buku. Faham radikalisme juga disebarkan melalui buku-buku, baik terjemahan dari bahasa Arab, yang umumnya ditulis oleh para penulis Timur Tengah, maupun tulisan mereka sendiri. Tumbangnya pemerintahan Soeharto membuat kelompokkelompok radikal yang dulu tiarap menjadi bangun kembali. Euforia reformasi ternyata juga berimbas dengan masuknya buku-buku berideologi radikal seperti jihad dari Timur Tengah ke Indonesia. Para penerbit pun tidak segan-segan untuk menerbitkan buku-buku terjemahan tersebut kepada masayarakat.

5. Melalui lembaga pendidikan. Sekolah atau kampus menjadi salah satu target penyebaran faham radikal. Dipilihnya pemuda adalah rasa keingintahuan mereka yang cukup besar untuk memahami sesuatu. Ketika keinginan itu ada, apapun jalan dan caranya akan dilakukan. Keadaan seperti inilah yang dimanfaatkan oleh kelompok radikal untuk mengajak mereka dalam diskusi serta kegiatan kelompok radikal. Awal mulanya hanya sebatas diskusi dan kegiatan sosial lainnya. Setelah semua sudah merasakan kecocokan, baru wawasan keilmuan akan diarahkan pada masalah jihad atau sejenisnya. Selain rasa ingin tahu, minimnya pengetahuan agama juga menjadi kelemahan untuk memahami makna perjuangan. Seringkali yang dijadikan sasaran utama adalah kampus-kampus umum yang notabennya para mahasiswanya masih dianggap minim dalam memahami agama. Kekurangan ini menjadi sebuah keuntungan bagi kelompok radikal untuk memberikan banyak pengetahuan melalui 
dalil-dalil tertentu sehingga mereka percaya dan dituntut untuk mengamalkannya ${ }^{15}$.

\section{E. Upaya Sekolah dalam Menangkal Radikalisme}

Fenomena gerakan radikal Islam yang muncul di masyarakat, dikhawatirkan akan dapat merambah di kalangan pemuda, terutama siswa di sekolah. Adanya keresahan tersebut, maka perlu diambil langkahlangkah cepat agar paham tersebut tidak dapat mencemari pikiran siswa di sekolah $^{16}$. Beberapa upaya dapat dilakukan pihak sekolah untuk menangkal radikalisme, antara lain;

\section{Memberikan Penjelasan tentang Islam Secara Memadai.}

Tujuan ajaran Islam yang sebenarnya sangat mulia dan luhur seringkali justru mengalami distorsi akibat pemahaman yang keliru terhadap beberapa aspek ajaran Islam yang berpotensi menimbulkan faham radikalisme. Berikut contoh pemahaman yang harus disampaikan kepada siswa;

a) Penjelasan tentang jihad. Makna jihad yang sebenarnya harus dipahami dengan baik dan disosialisasikan kepada seluruh khalayak umum agar tidak terjadi miskonsepsi tentang konsep jihad dalam Islam. Dalam Ensiklopedi Islam Indonesia misalnya, makna kata "jihad" diartikan: berbuat sesuatu secara maksimal, atau mengorbankan segala kemampuan. Arti lain dari kata jihad adalah berjuang/ sungguh-sungguh. Namun, bila dilihat dari sudut ilmu fiqh, jihad dapat dimaknai secara kontekstual sehingga dapat memiliki maksud yang berbeda-beda. Pemaknaan jihad yang berbeda-beda tersebut mempunyai akibat hukum syariat yang berbeda dan kadang bersinggungan dengan akidah. Sebagian ulama memaknai jihad sebagai usaha "mengerahkan segala kemampuan yang ada atau sesuatu yang dimiliki untuk menegakkan kebenaran dan kebaikan serta menentang kebatilan dan kejelekan dengan mengharap ridla Allah"17. Dari makna tersebut kita dapat mengambil kesimpulan bahwa jihad adalah bersungguh-sungguh dalam menegakkan kebenaran dengan mengaharap ridlo Allah Swt

15 Abdul, Munip, Menangkal Radikalisme di sekolah, (Jurnal pendidikan Islam Vol 1 No. 2 Badan Litbang dan Diklat Departemen Agama RI, Desember 2012), hal. 167 16 Ibid., hal. 174

${ }_{17}$ IAIN Syarif Hidayatullah, Ensiklopedi Islam Indonesia (Jakarta: Djambatan, 1992), hal. 110 
serta tidak menimbulkan masalah di dalamnya. Apabila melakukan tindak kebenaran, namun di dalam cara mensikapinya menimbulkan permasalahan baru, maka itu bukan termasuk jihad yang semestinya.

b) Penjelasan tentang toleransi. Diakui atau tidak, setiap agama pasti memiliki doktrin tertentu agar pemeluknya senantiasa patuh terhadap ajaran agama. Namun, doktrin ini tidak lantas menutup pintu bagi pemeluknya untuk tidak melakukan hubungan sosial dengan pemeluk agama lain. Islam hadir bukan semata-mata untuk memberikan kebahagiaan dan kesejahteraan bagi pemeluknya, melainkan juga untuk mewarnai kehidupan di muka bumi ini. Toleransi di sini lebih bersifat hubungan horisontal, yakni antar sesama manusia sebagai ciptaan Allah Swt. Sejatinya diantara kita (manusia) diperintahkan untuk saling mengenal sekaligus saling menghormati antar sesama18. Selanjutnya al-Quran telah menegaskan juga bahwa Islam sebagai rahmat bagi alam semesta, secara gamblang mengakui kemajemukan keyakinan dan agama. Ratusan ayat telah menjelaskan secara detail untuk bersikap toleran dengan pemeluk agama lain. Jika diteliti lebih lanjut, alQuran merupakan lumbung ajaran toleransi yang mengajarkan perdamaian.

c) Pengenalan tentang ajaran Islam dengan kearifan lokal. Islam yang berada di Arab sangatlah berbeda dengan Islam di Indonesia. Dalam pengertian, cara memahami Islam pun berbeda. Hal ini dikarenakan kondisi sosio-historis masyarakat Indonesia yang juga telah memiliki budaya tersendiri. Dengan pemahaman seperti ini, Islam dapat diterima dan hidup secara berdampingan dengan tradisi lokal yang sudah mengalami proses Islamisasi. Pemahaman dan pengamalan ajaran Islam yang formal, puritan, dan kering, justru kurang dapat menyentuh aspek terdalam dari spiritualitas manusia muslim itu sendiri.

\section{Mengedepankan dialog dalam Pembelajaran Agama Islam.}

Dialog dalam pembelajaran agama merupakan salah satu upaya tepat untuk menangkal radikalisme di sekolah. Seringnya dilakukan dialog antara siswa dengan siswa atau guru dengan siswa, akan menambah wawasan keberagamaan siswa dalam memaknai Islam itu sendiri. Dari

\footnotetext{
${ }^{18}$ Zuhairi Misrawi, Al-Quran Kitab Toleransi (Jakarta: Grasindo, 2010), hal. 75
} 
sini, guru dapat memberikan pengetahuan tentang adanya perbedaan madzhab dalam Islam, sehingga melalui dialog tersebut guru dapat memberikan pengertian bahwa di dalam Islam memiliki banyak perbedaan dalam cara pandang dalam keberagamaan. Setidaknya, adanya keberbedaan harus disikapi dengan arif dan bijaksana agar hubungan baik antar sesama pemeluk agama Islam terus berjalan dengan baik. Dialog menjadi cara tepat dalam penyampaian ide atau gagasan, bukan kekerasan yang dapat memberikan solusi atas setiap permasalahan yang ada.

3. Pemantauan terhadap Kegiatan dan Materi Monitoring Keagamaan.

Kegiatan monitoring yang dilakukan oleh pihak sekolah sangat membantu dalam proses penyebaran paham radikal di sekolah. Pemantauan yang intensif dan berkelanjutan akan mempersempit ruang gerak bagi mereka yang ingin menyebarkan misi tertentu. Kerjasama pihak sekolah dengan pengurus rohani Islam perlu dilakukan secara intens, sehingga setiap perkembangan atau kejadian yang ada dapat dipantau secara bersama-sama. Apabila terjadi keganjalan, dengan segera pengurus Rohis di sekolah mengkomunikasikan dengan pihak guru/ sekolah agar dapat ditanggulangi secara cepat.

\section{Pengenalan dan Penerapan Pendidikan Multikultural.}

Pendidikan multikultural pada dasarnya adalah konsep dan praktek pendidikan yang mengedepankan nilai-nilai persamaan tanpa melihat perbedaan latar belakang budaya, sosial-ekonomi, etnis, agama, gender, dan lain-lain. Semua orang memiliki kesempatan yang sama untuk memperoleh hak pendidikan. Dengan penerapan pendidikan multikultural, diharapkan semangat eksklusif dan merasa benar sendiri sebagai penyebab terjadinya konflik dengan yang lain dapat terhindarkan. Seorang multukulturalis sejati adalah pribadi yang selalu bersikap toleran, menghargai keberadaan orang lain tanpa dia sendiri kehilangan identitasnya. Kalau tujuan akhir pendidikan adalah perubahan perilaku dan sikap serta kualitas seseorang, maka pengajaran harus berlangsung sedemikian rupa, sehingga tidak sekedar memberi informasi atau pengetahuan melainkan harus menyentuh hati, sehingga akan mendorong siswa dapat mengambil 
keputusan untuk berubah ${ }^{19}$. Pendidikan Agama selain bertujuan untuk memperteguh keyakinan pada agamanya, juga harus diorientasikan untuk menanamkan empati, simpati dan solidaritas terhadap sesama.

\section{Simpulan}

Agama Islam mengajarkan tentang toleransi, rahmat bagi seluruh alam, serta diperintahkan bagi pemeluknya untuk hidup secara berdampingan dan damai. Meski banyak perberbedaan pandangan dalam memaknai Islam, itu sebuah kewajaran, karena itu merupakan bagian sunnatullah yang tidak dapat terelakkan. Faham radikal dalam Islam menjadi persoalan serius untuk ditanggulangi secara bersama agar tidak merambah pada generasi muda Islam. Oleh karena itu, seluruh lapisan masyarakat harus bertanggungjawab dalam mengatasi masalah tersebut, termasuk peran lembaga pendidikan dalam menanggulanginya. Sekolah menjadi bagian yang penting dalam pencegahan faham radikal tersebut, karena banyak kaum muda yang menjadi sasaran tembak dalam penyebaran faham ini. Ada beberapa hal yang dapat dilakukan sekolah dalam menanggulangi radikalisme di antaranya; a) memberikan penjelasan ajaran Islam secara memadai; b) mengedepankan dialog dalam pembelajaran agama; c) Pemantauan terhadap Kegiatan dan Materi Monitoring Keagamaan; d) pengenalan dan penerapan pendidikan multikultural.

19 Kemenag, Panduan Model Kurikulum PAI Berbasis Multikultural (Jakarta: Ditjen Pendis, 2010), hal. 25 


\section{DAFTAR PUSTAKA}

Bakhri, Syamsul. Islam dan Wacana Radikalisme Agama Kontemporer. Jurnal DINIKA Vol 3. No. 1 January, 2004.

Hasani et. all, Ismail, Radikalisme Islam di Jabotabek dan Jawa barat: Implikasinya terhadap Jaminan Kebebasan Beragama/ Berkeyakinan, Jakarta: Setara Institute, 2011

http://international.sindonews.com/read/889847/43/isis-bunuh-500warga-yazidi-korban-dikubur-hidup-hidup diunduh pada tanggal 1 Oktober 2014.

http://www.indozaman.com/cendekiawan-turki-fethullah-gulen-prihatinatas-jatuhnya-korban-akibat-militan-isis/ diunduh pada tanggal 1 Oktober 2014.

http://jabar.tribunnews.com/korban-tewas-penembakan-dan-bombunuh-diri-di-paris-jadi-153-orang pada tanggal 14 November 2015.

IAIN Syarif Hidayatullah, Ensiklopedi Islam Indonesia, Jakarta: Djambatan, 1992

Imarah, Muhammad. Fundamentalisme dalam Perspektif Barat dan Islam, Terjemahan Abdul Hayyie al-Kattani, Jakarta: Gema Insani Press, 1999

Kuntowijoyo, Identitas politik Umat Islam, Bandung: Mizan, 1997

Madjid, Nurcholis, Islam Agama Peradaban; Mencari Makna dan Relevansi Doktrin Islam dalam Sejarah, Jakarta: Paramadina, 1995

Misrawi, Zuhairi, Al-Quran Kitab Toleransi, Jakarta: Grasindo, 2010

Muhammad, Afif, Agama dan Konflik Sosial; Studi Pengalaman di Indonesia, Bandung: Marja, 2013

Munip, Abdul. Menangkal Radikalisme di sekolah. Jurnal pendidikan Islam Vol 1 No. 2 Desember 2012 Badan Litbang dan Diklat Departemen Agama RI.

Nasution, Harun, Islam Rasional. Bandung: Mizan, 1995

Nuhrison M. Nuh. Faktor-faktor Penyebab Munculnya Faham atau Gerakan Islam Radikal di Indonesia. Jurnal Harmoni Vol.VIII, No. 30, April Juni 2009. 
Pusat Bahasa Depdiknas RI, Kamus Bahasa Indonesia. Jakarta: Depdiknas, 2008

Suradinata, Ermaya, Radikalisme dan Masa Depan Bangsa. Makalah Seminar Nasional "Masa Depan Bangsa dan Radikalisme Agama" diselenggarakan oleh Fakultas Ushuluddin, IAIN Sunan Gunung Jati Bandung pada tanggal 17 Juni 2004.

Tim Penyusun DITPAIS Kemenag, Panduan Model Kurikulum PAI Berbasis Multikultural, Jakarta : Ditjen Pendis, 2010

Zada, Khamami, Islam Radikal; Pergulatan Ormas-ormas Islam Garis Keras di Indonesia, Jakarta: Teraju, 2002 